\title{
IMPLEMENTASI MODEL PEMBELAJARAN KOOPERATIF TIPE NHTDENGAN MENGGUNAKAN PERIODIC TABLE EXPLORER (PT-e) UNTUK MENINGKATKAN HASIL BELAJAR PADA SISWA KELAS XI IPA 1 SMA NEGERI 4 PALOPO
}

\author{
Oleh: Andi Irawati Indal Patra
}

\begin{abstract}
Abstrak:
Telah dilakukan penelitian tentang implementasi model pembelajaran kooperatif tife NHT dengan menggunakan Periodic Table Explorer (PT-e) untuk meningkatkan hasil belajar pada siswa kelas XI IPA 1 SMA Negeri 4 palopo. Penelitian ini bersifat kaji tindak atau rancangan penelitian tindakan kelas (classroom action research) yang lakukan secara berdaur (siklus). Subjek penelitian ini adalah siswa Kelas XI SMA Negeri 4 Palopo yang berjumlah 30 orang, terdiri dari 4 orang laki-laki dan 26 orang perempuan. Penelitian ini dilaksanakan sebanyak dua siklus dengan tiga kali pertemuan setiap siklusnya, alokasi waktu $2 x$ 45 menit tiap pertemuan. Tahapan pelaksanaan penelitian setiap siklus terdiri atas empat tahapan utama yaitu (1) perencanaan, (2) tindakan, (3) pengamatan, (4) refleksi. Data hasil pengamatan mengenai aktivitas siswa dalam proses belajar mengajar pada siklus dua sudah sangat baik dibandingkan siklus pertama. Penelitian tentang hasil belajar siswa pada siklus 1 diperoleh siswa yang mendapat nilai $\geq 66$ adalah 19 orang atau 63\% dan masuk dalam kategori tuntas. Siswa yang mendapat nilai $\leq 65$ adalah 11 orang = 37\% masuk dalam kategori belum tuntas dengan nilai rata-rata siswa 72,1. Hasil penelitian siklus 2 diperoleh siswa yang mendapat nilai $\geq 66$ adalah 26 orang (tuntas) sedangkan siswa yang mendapat nilai $\leq 65$ adalah 4 siswa (belum tuntas) dengan nilai ratarata siswa 79,4. Dari data tersebut dapat disimpulkan bahwa melalui implementasi model pembelajaran kooperatif tife NHT dengan menggunakan periodic table explorer (PT-e) pada materi struktur atom dan sistem periodik, hasil belajar siswa kelas XI IPA 1 tahun 2012 / 2013 SMA Negeri 4 Palopo dapat ditingkatkan
\end{abstract}

Kata Kunci: Numbered Heads Together (NHT, Periodic Table Explorer PT-e), Hasil belajar siswa. 


\section{Pendahuluan}

Pembangunan di bidang pendidikan merupakan sarana dan wahana dalam pembinaan sumber daya manusia. Oleh karena itu pendidikan perlu mendapatkan perhatian dalam penanganannya baik dari pemerintah, keluarga atau masyarakat, serta pengelola pendidikan itu sendiri. Lembaga pendidikan senantiasa mengadakan peningkatan dan penyempurnaan terhadap mutu pendidikan. Salah satu diantaranya adalah melalui penggunaan metode dan strategi pengajar yang tepat dalam proses belajar mengajar. Metode serta strategi mengajar mempunyai peranan yang sangat penting, karena strategi mengajar merupakan salah satu penunjang utama berhasil atau tidaknya seorang dalam mengajar.

Menurut Sullivan (dalam Upu : 2003) bahwa pengajaran di kelas pada umumnya hanya berpusat pada guru yang mengakibatkan siswa menjadi malas dan kurang bergairah dalam menerima pelajaran. Ini menunjukkan bahwa salah satu penyebab kurang berpartisipasinya siswa dalam pengajaran karena penerapan metode serta strategi mengajar yang kurang tepat. Kenyataan di kelas menunjukkan bahwa sebagian besar siswa kelas XI mengalami kesulitan dalam menuliskan konfigurasi elektron padahal sebelumnya dikelas X sudah dipelajari atom, struktur dan konfigurasi elektron serta hubungannya dengan golongan dan periode suatu unsur. Hal ini terbukti dengan rendahnya nilai mata pelajaran baik dalam tes formatif maupun tes sumatif disebabkan siswa tidak mampu menyelesaikan soal-soal menuliskan konfigurasi elektron dan hubungannya dengan sistem periodik menggunakan teori atom modern. Kecenderungan ini juga nampak terjadi pada siswa kelas XI IPA SMA Negeri 4 Palopo di mana peneliti mengajar. Nilai rata-rata siswa untuk materi struktur atom dan sistem periodik pada tahun pelajaran 2011-2012 adalah 68,0. Nilai ini sangat rendah jika dilihat dari nilai KKM yang ditetapkan yaitu 70. Salah satu metode mengajar yang dianggap mampu mengaktifkan siswa dalam pengajaran adalah metode Numbered Heads Together (NHT). Metode ini dapat melibatkan siswa secara 
aktif dalam pembelajaran, sehingga diharapkan akan terjadi pertukaran informasi antara guru dan siswa atau mengubah kecenderungan dari teacher-centred ke student-centered.

Kreativitas guru di dalam menerapkan praktek visualisasi pada pembelajaran ilmu kimia juga perlu dilakukan mengingat ilmu kimia dalam pembelajarannya seringkali membutuhkan metoda yang lebih bersifat eksperimental daripada hanya sekedar pengajaran lisan. Hal ini akan memberi tambahan minat bagi siswa untuk lebih bergairah mempelajari ilmu kimia secara lebih baik serta dapat memberi nilai lebih bagi sekolah yang bersangkutan khususnya dalam rangka pelaksanaan kurikulum berbasis kompetensi. Adanya perkembangan teknologi komputer baik dari segi perangkat keras maupun perangkat lunak memungkinkan untuk pemodelan atom dan molekul dengan menggunakan komputer. Saat ini banyak sekali software-software yang dapat digunakan untuk aplikasi visualisasi dalam pembelajaran kimia, baik software yang bersifat komersial maupun yang bersifat freeware (gratis) atau shareware (gratis untuk sementara waktu atau gratis untuk software versi terbatas).

Beranjak dari kondisi tersebut di atas maka penulis mencoba memanfaatkan program periodic table explorer yang merupakan salah satu softwere kimia yang bersifat freeware, Software ini dapat didownload secara gratis dari internet dan merupakan alternatif pembelajaran yang diharapkan dapat lebih menarik minat siswa untuk mempelajari ilmu kimia. Berdasaran uraian di atas dilakukan penelitian tindakan kelas dengan judul: Implementasi model pembelajaran kooperatif tife NHT dengan menggunakan periodic table explorer (PT-e) untuk meningkatkan hasil belajar pada siswa kelas XI IPA 1 SMA Negeri 4 Palopo.

\section{Kajian Pustaka}

A. Pembelajaran dengan Model Numbered Heads Together (NHT)

Salah satu tipe dari model pembelajaran kooperatif adalah Number Head Together (NHT). Teknik Belajar Number head together (NHT) dikembangkan oleh Spencer Kagan (1992). Secara 
garis besar belajar mengajar dengan metode $N H T$ ini dapat dikemukakan sebagai berikut:

1. Siswa dibagi dalam kelompok, setiap siswa dalam setiap kelompok mendapat nomor

2. Guru memberikan tugas dan masing-masing kelompok mengerjakannya

3. Kelompok mendiskusikan jawaban yang benar dan memastikan tiap anggota kelompok dapat mengerjakannya/mengetahui jawabannya

4. Guru memanggil salah satu nomor siswa dengan nomor yang dipanggil melaporkan hasil kerjasama mereka

5. Tanggapan dari teman yang lain, kemudian guru menunjuk nomor yang lain

6. Kesimpulan (Indrawati, 2007)

Menurut Anita Lie (2002) prosedur teknik number head together adalah saat pemanggilan siswa untuk menjawab atau melakukan sesuatu yang dipanggil adalah nomor kepala dari salah satu kelompok secara acak. Hal ini akan menyebabkan semua siswa harus siap. Dan penghargaan diberikan jika jawaban benar untuk nilai kelompok. Menurut Bobbi De Porter (2001) siswa akan belajar paling baik dalam lingkungan kerja sama. Belajar yang menekankan pada kerja sama diantara sesama siswa dalam suatu komunikasi belajar dapat lebih menggairahkan.

Ada beberapa manfaat pada model pembelajaran kooperatif tipe NHT terhadap siswa yang hasil belajar rendah yang dikemukakan oleh Lundgren dalam Ibrahim (2000: 18), antara lain adalah : Rasa harga diri menjadi lebih tinggi, memperbaiki kehadiran, penerimaan terhadap individu menjadi lebih besar, perilaku mengganggu menjadi lebih kecil, konflik antara pribadi berkurang, pemahaman yang lebih mendalam, meningkatkan kebaikan budi, kepekaan dan toleransi, hasil belajar lebih tinggi. Disamping kelebihan tersebut menurut pandangan penulis, metode NHT mempunyai beberapa kekurangan yakni menyita lebih banyak waktu bagi pengajar, khususnya untuk mengoreksi hasil kerjasama siswa dari tugas yang diberikan. 
Menurut Sudjana (2000) strategi adalah suatu pola yang direncanakan dan ditetapkan secara sengaja untuk melakukan kegiatan atau tindakan. Menurut Sahabuddin (1998) Belajar merupakan aktifitas yang dilakukan seseorang atau peserta didik secara pribadi dan sepihak. Menurut M. Subana (2000), kata belajar berarti suatu proses perubahan tingkah laku pada siswa akibat adanya interaksi antara individu dan lingkungannya melalui proses pengalaman dan latihan.

\section{B. Periodic Table Explorer (PT-e)}

Periodic Table Explorer (PT-e) adalah suatu software aplikasi kimia yang mudah didapatkan melalui jaringan internet. Aplikasi ini berisi semua unsur-unsur dari tabel periodik beserta dengan gambar dari unsur-unsur, serta banyak informasi lain dengan penampilkan interaktif. Dilengkapi dengan 173 gambar resolusi tinggi dari unsur-unsur dalam keadaan fisik yang berbeda. Dirancang untuk dijalankan pada desktop dengan resolusi $1024 \times$ 768 atau lebih tinggi. Tampilan PT-e dapat dilihat pada gambar 2.1

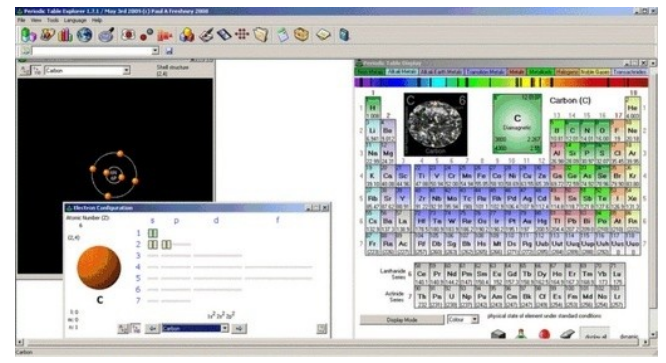

Gambar 2.1. Tampilan Periodik Table Explorer (PT-e)

Kumpulan informasi unsur-unsur kimia yang ada di alam semesta. Disertai gambar yang lengkap, sehingga lebih mudah dipahami. Terdapat fitur penting lainnya yang sangat berguna bagi para pecinta kimia. Perangkat lunak ini menampilkan cara baru bagaimana menjelajahi tabel periodik. Setiap layar dapat dibuka beberapa kali, dan dapat menampilkan informasi yang berbeda. Ukuran, bentuk dan posisi dari setiap layar dapat disesuaikan juga. 
Noor laela maftuchah (2011) telah melakukan penelitian mengenai pengaruh pengetahuan, kegunaan dan penggunaan media berbasis ICT terhadap efektivitas pembelajaran guru ekonomi-akuntansi di SMA se-kabupaten kudus tahun ajaran 2009/2010. Kesimpulan dalam penelitian ini yaitu terdapat pengaruh pengetahuan, kegunaan dan penggunaan media berbasis ICT yang signifikan terhadap efektivitas pembelajaran Guru Ekonomi-Akuntansi di SMA Se-Kabupaten Kudus Tahun 2009/2010. Penelitian lainnya yang dilakukan oleh Nova Dela Ria Ika Sejati (2011) yang telah melakukan penelitian mengenai pemanfaatan media pembelajaran pendidikan kewarganegaraan berbasis TIK. Hasil penelitian menunjukkan bahwa pemanfaatan media pembelajaran berbasis TIK dalam pembelajaran PPKN di SMP Negeri 5 Semarang kurang dimanfaatkan dengan baik karena masih ada media atau alat bantu yang tersedia tetapi tidak dimanfaatkan dalam pembelajaran, selain itu ada kendala lain yaitu guru juga kurang mampu dalam mengoperasikan media berbasis TIK.

\section{Hipotesis}

Jika model pembelajaran kooferatif tife $N H T$ dengan menggunakan Periodic Table explorer(PT-e) diterapkan maka hasil belajar siswa kelas XI IPA 1 SMA Negeri 4 Palopo dapat ditingkatkan.

\section{Metode Penelitian}

A. Desain Penelitian

Penelitian ini bersifat kaji tindak atau rancangan penelitian tindakan kelas ( classroom action research). Mekanismenya dilakukan secara berdaur (siklus).

Secara umum alur pelaksanaan tindakan dalam penelitian tindakan kelas ini digambarkan Oleh Kemmis dan Taggart sebagaimana gambar 3.1 


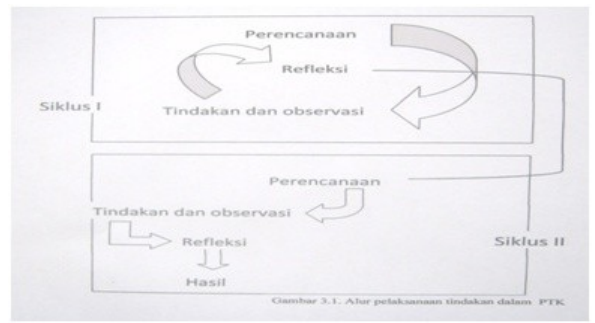

\section{Gambar 3.1. Siklus PTK}

B. Faktor yang Diselidiki

Faktor yang diselidiki dalam penelitian ini adalah :

1. Faktor Siswa : yaitu aktivitas siswa selama pembelajaran baik aktivitas di dalam tugas maupun di luar tugas, terutama interaksi siswa dengan siswa lainnya dalam proses pembelajaran kimia

2. Faktor Guru : yaitu aktivitas Guru dalam memfasilitasi interaksi siswa selama proses pembelajaran berlangsung.

3. Faktor Hasil : yaitu hasil belajar berupa prestasi belajar kimia dan persepsi siswa terhadap pembelajaran.

\section{Pelaksanaan Penelitian}

Penelitian ini dilaksanakan sebanyak dua siklus dengan tiga kali pertemuan setiap siklusnya, alokasi waktu $2 \times 45$ menit tiap pertemuan. Tahapan pelaksanaan penelitian setiap siklus terdiri atas empat tahapan utama yaitu (1) perencanaan, (2) tindakan, (3) pengamatan, (4) refleksi sebagaimana disajikan pada tabel 3.1

Tabel 3.1. Pokok-pokok Tahapan Pelaksanaan Penelitian

\begin{tabular}{|c|c|c|}
\hline Siklus & & Tahapan-Tahapan \\
\hline I & $\begin{array}{l}\text { Perencanaan: } \\
\text { Identifikasi } \\
\text { masalah dan } \\
\text { penetapan } \\
\text { alternatif } \\
\text { pemecahan } \\
\text { masalah }\end{array}$ & $\begin{array}{l}\text { - Merencanakan pembelajaran yang akan } \\
\text { diterapkan dalam PBM } \\
\text { - Menentukan pokok bahasan } \\
\text { - Mengembangkan skenario pembelajaran } \\
\text { - Menyusun LKS } \\
\text { - Menyiapkan sumber belajar } \\
\text { - Mengembangkan format evaluasi } \\
\text { - Mengembangkan format observasi pembelajaran }\end{array}$ \\
\hline
\end{tabular}


Implementasi Model Pembelajaran Kooperatif Tipe NHT dengan

Menggunakan Periodic Table Explorer (PT-e) untuk Meningkatkan Hasil

Belajar pada Siswa Kelas XI IPA 1 SMA Negeri 4 Palopo

\begin{tabular}{|c|c|c|}
\hline & Tindakan & $\begin{array}{l}\text { - Menerapkan tindakan mengacu pada skenario } \\
\text { yang direncanakan dan LKS }\end{array}$ \\
\hline & Pengamatan & $\begin{array}{l}\text { - Melakukan observasi dengan memakai format } \\
\text { observasi } \\
\text { - Menilai hasil tindakan dengan menggunakan } \\
\text { format LKS }\end{array}$ \\
\hline & Refleksi & $\begin{array}{l}\text { - Melakukan evaluasi tindakan yang telah } \\
\text { dilakukan, meliputi evaluasi mutu, jumlah dan } \\
\text { waktu dari setiap macam tindakan } \\
\text { - Melakukan pertemuan untuk membahas hasil } \\
\text { evaluasi tentang skenario, LKS, dll. } \\
\text { - Memperbaiki pelaksanaan tindakan sesuai hasil } \\
\text { evaluai, untuk digunakan pada siklus } \\
\text { berikutnya. } \\
\text { - Evaluasi tindakan I }\end{array}$ \\
\hline II & Perencanaan & $\begin{array}{l}\text { - Identifikasi masalah dan penetapan alternatif } \\
\text { pemecahan masalah } \\
\text { - Pengembangan program tindakan II }\end{array}$ \\
\hline & Tindakan & Pelaksanaan program tindakan II \\
\hline & Pengamatan & Pengumpulan data tindakan II \\
\hline & Refleksi & Evaluasi tindakan II \\
\hline
\end{tabular}

D. Cara Pengambilan Data

Pengumpulan data dilakukan dengan cara:

1. Observasi aktivitas siswa selama proses pembelajaran berlangsung untuk setiap pertemuan.

2. Memberikan tes hasil belajar setiap akhir siklus yaitu akhir siklus I dan akhir siklus II.

3. Memberikan angket / kuesioner tentang persepsi siswa terhadap pembelajaran pada akhir siklus II

Kriteria hasil penelitian tentang penguasaan materi " pokok bahasan menuliskan konfigurasi elektron dan hubungannya dengan sistem periodik menggunakan teori atom modern dan aktivitas siswa dapat dilihat pada tabel 3.2 dan 3.3

Table 3.2. Kriteria nilai penguasaan materi menuliskan konfigurasi elektron dan hubungannya dengan sistem periodik menggunakan teori atom modern

\begin{tabular}{|c|c|c|}
\hline No & Nilai & Kriteria \\
\hline 1 & $\leq 69$ & Kurang \\
\hline
\end{tabular}


Implementasi Model Pembelajaran Kooperatif Tipe NHT dengan

Menggunakan Periodic Table Explorer (PT-e) untuk Meningkatkan Hasil

Belajar pada Siswa Kelas XI IPA 1 SMA Negeri 4 Palopo

\begin{tabular}{|c|c|c|}
\hline 2 & $70-79$ & Sedang \\
\hline 3 & $80-89$ & Baik \\
\hline 4 & $90-100$ & Baik Sekali \\
\hline
\end{tabular}

(Sosialisasi KTSP 2007, penilain kelas SMA, Departemen Pendidikan Nasional Badan Penelitian dan Pengembangan Pendidikan Nasional Pusat Kurikulum)

Pedoman penialainnya adalah sebagai berikut:

$$
\text { Nilai }=\frac{\text { Skor Perolehan }}{\text { Skor maximum }} \times 100
$$

Table 3.3 Kriteria aktivitas siswa dalam proses pembelajaran

\begin{tabular}{|c|c|c|c|c|c|c|c|}
\hline \multirow{2}{*}{$\mathrm{No}$} & \multirow{2}{*}{ Aktivitas } & \multirow{2}{*}{\begin{tabular}{|c|}
$\Sigma$ \\
Siswa
\end{tabular}} & \multirow{2}{*}{$\%$} & \multicolumn{4}{|c|}{ Skala Penilaian } \\
\hline & & & & $\overline{\mathbf{A}}$ & $\mathbf{B}$ & $\mathbf{C}$ & $\mathbf{D}$ \\
\hline & Kehadiran Siswa dalam mengikuti pelajaran & & & & & & \\
\hline & Siswa mengikuti pelajaran dengan serius & & & & & & \\
\hline & Siswa mencatat pelajaran & & & & & & \\
\hline & Siswa berani menjawab tanpa ditunjuk & & & & & & \\
\hline & Efektifitas pembentukan kelompok & & & & & & \\
\hline & $\begin{array}{l}\text { Kerjasama dengan teman-teman dalam satu } \\
\text { kelompok }\end{array}$ & & & & & & \\
\hline & Siswa mengerjakan LKS & & & & & & \\
\hline & Siswa bertanya ke guru bila ada yg tidak jelas & & & & & & \\
\hline 9 & Ketepatan mengumpulkan hasil diskusi & & & & & & \\
\hline 10 & Siswa mengerjakan soal latihan/ tes & & & & & & \\
\hline
\end{tabular}

(Sosialisasi KTSP 2007, penilain kelas SMA, Departemen Pendidikan Nasional Badan Penelitian dan Pengembangan Pendidikan Nasional Pusat Kurikulum)

Keterangan:

Skala penilaian di isi dengan tanda (V)

Diisi pada waktu PBM berlangsung dengan ketentuan sebagai berikut:

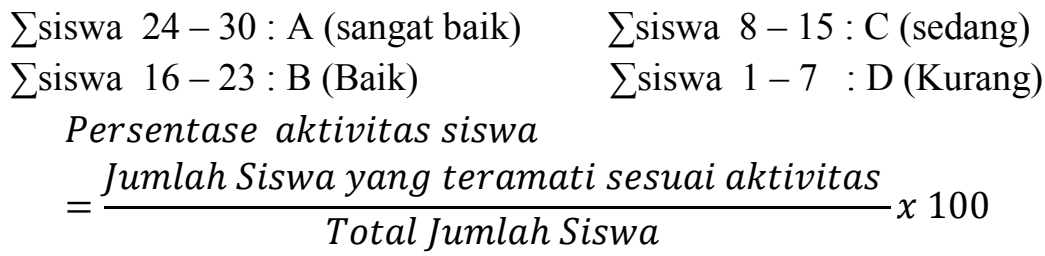




\section{E. Indikator Keberhasilan}

Berdasarkan kriteria ketuntasan minimal (KKM) berdasarkan kompetensi dasar yang berlaku di SMA Negeri 4 Palopo. Indikator keberhasilan yang digunakan dalam penelitian ini adalah : Pemanfaatan periodic table explorer untuk meningkatkan hasil belajar melalui implementasi model pembelajaran kooperatif tife NHT dikatakan meningkat jika:

1. Minimal $80 \%$ siswa memperoleh nilai kriteria ketuntasan minimal individu $\geq$ KKM.

2. Minimal $80 \%$ aktivitas siswa meningkat dari siklus I ke siklus II.

\section{Hasil Penelitian dan Pembahasan}

A. Hasil Penelitian Siklus I

Hasil penelitian di siklus I adlah sebagai berikut:

1. Hasil Observasi Terhadap Siswa

a. Sebelum pelajaran dimulai guru mengabsen kehadiran siswa, ternyata siswa aktif masuk semua.

b. Saat menerima penjelasan dari guru ada beberapa anak yang duduk di belakang asyik bermain dan asyik berbicara dengan temannya.

c. Saat guru memberi pertanyaan siswa sudah berani menjawab tanpa disuruh / ditunjuk walaupun masih ada beberapa siswa yang pasif.

d. Saat pembentukan kelompok masih ada siswa yamng berebut tempat duduk sehingga kelas agak gaduh, perlu pembenahan untuk siklus berikutnya supaya siswa menjadi lebih tertib.

e. Saat mengerjakan lembar kerja ada siswa yang aktif ada yang pasif, ini menunjukkan mereka belum biasa bekerja dalam kelompok secara optimal.

f. Sebagian besar yang aktif hanya siswa yang pandai, siswa yang kurang pandai terlihat asyik bermain sendiri dengan temannya.

g. Bagi siswa yang kemampuan sedang ke bawah mengalami kesulitan untuk mengerjakan soal-soal struktur atom dan 
sistem periodik dan dibuktikan dengan berkalikali bertanya kepada guru.

h. Soal yang diberikan tiap-tiap siswa dalam kelompok yang terdiri dari 4 siswa mempunyai tingkat kesukaran yang berbedabeda, akibatnya anak yang merasa mendapat nomor soal yang sukar menjadi pasif .

i. Saat pembahasan hasil presentasi, guru belum mengajak siswa mencermati langkah-langkah penyelesaian soal, akibatnya banyak siswa yang mengalami kesulitan pada soal menentukan bilangan kuantum, sehingga banyak pekerjaan kelompok yang salah.

j. Dari lembar kerja siswa yang dikerjakan ada kelompok yang benar semua, satukelompok ada yang belum sempurna dan yang lainnya belum memahami secara maksimal, yang benar di bawah $50 \%$.

k. Ada 7 siswa yang belum dapat menuliskan konfigurasi elektron sehingga mengalami kesulitan dalam menyelesaikan soal-soal struktur atom secara sistematis.

B. Hasil Observasi Pada Guru

a. Guru sudah menyediakan media dalam proses belajar mengajar, yaitu LCD Proyektor, laptop, white boart serta software periodic table explorer .

b. Dalam membuka pelajaran sudah ada apersepsi mengkondisikan kelas dan menghubungkan materi yang akan dipelajari dengan benda-benda di lingkungan sekitar siswa.

c. Guru sudah mengorganisasikan siswa ke dalam kelompok kooperatif dengan membagi kelompk terdiri dari 4 siswa secara heterogen, terdiri dari siswa pandai, sedang dan kurang. Masing-masing siswa dalam kelompok diberi nomor.

d. Guru memberi petunjuk dan penjelasan yang berkaitan dengan materi pelajaran.

e. Guru memberikan perhatian ke seluruh kelompok dan memberi bimbingan individu bagi siswa yang pasif, serta memberi kesempatan kepada siswa untuk menanyakan hal-hal yang belum dipahami 
f. Guru sudah berusaha pro aktif mendorong keterlibatan siswa dalam proses pembelajaran, namun masih ada siswa yang mengalami kesulitan dalam menyelesaikan soal- soal menentukan bilangan kuantum .

g. Guru kurang menggunakan waktu secara efektif dan efisien karena saat diskusi melampaui waktu yang ditetapkan sehingga untuk menyimpulkan materi agak kekurangan waktu.

h. Guru sudah menutup pelajaran dengan membimbing siswa membuat kesimpulan.

i. Kesan umum penampilan guru dalam pembelajaran ramah, pakaian rapi dan tegas.

C. Hasil Belajar Siswa

a. Semua siswa berusaha mengerjakan tugas soal tes walaupun ada yang bertanya jika menemui kesulitan.

b. Masih ada beberapa siswa yang belum menguasai materi dengan baik

c. Nilai siklus I berdasarkan evaluasi pada pokok bahasan struktur atom tertera pada tabel 4.1

Tabel 4.1 Hasil belajar siswa pada siklus 1

\begin{tabular}{|c|c|c|c|l|}
\hline No & Rentang Nilai & Frekwensi & Persentase (\%) & \multicolumn{1}{|c|}{ Kriteria } \\
\hline 1 & $\leq 69$ & 15 & 50 & Kurang \\
\hline 2 & $70-79$ & 5 & 17 & Sedang \\
\hline 3 & $80-89$ & 9 & 30 & Baik \\
\hline 4 & $90-100$ & 1 & 3 & Baik sekali \\
\hline
\end{tabular}

Siswa yang mendapat nilai $\geq 66$ adalah 19 siswa $=\frac{19}{30} \times 100 \%=$ $63 \%$ (tuntas) Siswa yang mendapat nilai $\leq 65$ adalah 11 siswa $=$ $\frac{11}{30} \times 100 \%=37 \%$ (belum tuntas)

Nilai rata-rata siswa 72,1

D. Hasil Penelitian Siklus 2

Pelaksanaan siklus ini materi struktur atom dan sistem periodik diperoleh pengamatan sebagai berikut: 


\section{Hasil Observasi Pada Siswa}

a. Sebelum pelajaran dimulai guru memperhatikan siswa, ternyata siswa aktif masuk semua.

b. Saat menerima pelajaran dari guru siswa memperhatikan dengan baik.

c. Saat guru memberi pertanyaan siswa aktif menjawab tanpa ditunjuk

d. Pada saat pembentukan kelompok siswa sudah mulai tertib dan rapi, karena kelompok sudah terbentuk sebelumnya.

e. Saat kerja sama dalam kelompok siswa untuk menyelesaikan lembar kerja siswa sudah aktif.

f. Anak-anak yang kurang berani tampil mempersentasikan hasil diskusi kelompok semakin berkuang, menjadi lebih proaktif.

g. Saat membahas hasi persentasi temannya masih ada sebagian kecil siswa yang kurang memperhatikan.

h. Setiap anggota kelompok yang ada di dalam kelas sudah berperan aktif dan merasa bertanggung jawab dalam kelompoknya masing-masing.

i. Siswa sudah menyelesaikan tugas dengan tepat waktu, pekerjaannya benar, lengkap dan terstruktur meskipun masih ada siswa yang belum dapat menyelesaikan soal menuliskan konfigurasi elektron secara benar.

2. Hasil Observasi Pada Guru

a. Guru sudah mengorganisir kelompok dan tempat duduk dengan rapi sehingga terjadi interaksi antara guru dan siswa dan interaksi siswa dengan siswa sehingga lebih tertib.

b. Guru sudah menyiapkan RP (Rencana Pembelajaran) lengkap dengan instrument-instrumennya.

c. Guru sudah menyediakan media yang diperlukan dalam proses belajar mengajar

d. Guru sudah berusaha merespon pertanyaan siswa dan ditawarkan pada siswa yang lain untuk ikut memikirkan jawaban, guru hanya memancing jawaban dengan mengurai pertanyaan siswa sendiri. 
e. Waktu pembelajaran secara efektif dan efisien sudah dapat terlaksana

f. Guru memberi kesempatan kepada semua siswa untuk mempersentasikan hasil kerjanya sesuai dengan nomor yang diperolehnya.

g. Guru sudah menutup pelajaran dengan membimbing siswa membuat kesimpulan

h. Kesan umum penampilan guru dalam pembelajaran ramah, pakaian rapi, posisi bervariasi dan tegas.

3. Hasil Belajar Siswa

Nilai siklus II berdasarkan evaluasi pada pokok bahasan struktur atom dan sistem periodik tertera pada tabel 4.2.

Tabel 4.2 Hasil belajar siswa pada siklus 2

\begin{tabular}{|c|c|c|c|l|}
\hline NO & Rentang Nilai & Frekwensi & Persentase (\%) & Kriteria \\
\hline 1 & $\leq 69$ & 7 & 23 & Kurang \\
\hline 2 & $70-79$ & 7 & 23 & Sedang \\
\hline 3 & $80-89$ & 13 & 43 & Baik \\
\hline 4 & $90-100$ & 3 & 10 & Baik sekali \\
\hline
\end{tabular}

Siswa yg mendapat nilai $\geq 66=26$ siswa $=(26 / 30) \times 100 \%=87 \%$ (tuntas). Sedangkan siswa yg mendapat nilai $\leq 65=4$ siswa $=$ $(4 / 30) \times 100 \%=13 \%$ (belum tuntas). Nilai rata-rata siswa 79,4. Untuk melihat perbandingan ketuntasan belajar siswa pada siklus 1 dan siklus 2 serta nilai rata-rata siswa tertera pada gambar 4.1.

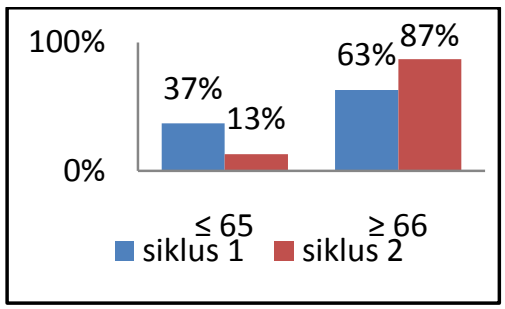

(a)

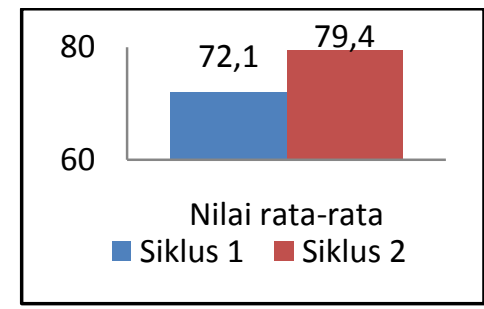

(b)

Gambar 4.1 (a). Persentase hasil belajar siswa pada siklus 1 dan siklus 2; (b). Perbandingan nilai rata-rata siswa pada siklus 1 dan siklus 2 


\section{Pembahasan}

Berdasarkan data yang ada pada tabel tersebut di atas, maka dapat dijelaskan bahwa:

a. Siklus Pertama

Dari hasil pengamatan aktivitas siswa dalam proses belajar mengajar tenyata dari 30 orang siswa telah mengikuti proses belajar mengajar dengan baik tetapi perlu ditingkatkan lagi. Dari 30 siswa terdapat 11 orang siswa (37\%) yang dapat dikatagorikan tidak tuntas belajar yaitu yang mendapat nilai $\leq 65$ sedang siswa yang tuntas belajar ada 19 siswa (63\%) dengan perolehan nilai rata-rata 72,1 dan daya serap terhadap materi pelajaran $72 \%$. Dengan demikian peneliti perlu melakukan tindakan selanjutnya untuk meningkatkan hasil belajar. Siswa dalam menyelesaikan soal struktur atom.

Jika melihat tabel hasil pengamatan oleh guru lain dapat dijelaskan bahwa dalam siklus pertama penguasaan guru terhadap materi pelajaran sudah baik, tetapi perhatian guru kurang merata pada seluruh siswa sehingga ada beberapa siswa yang kurang aktifdan sibuk bermain sendiri.

b. Siklus Kedua

Pada siklus kedua ini, aktivitas siswa dalam proses belajar mengajar sudah sangat baik dibandingkan siklus pertama. Dari hasil prestasi siswa juga terjadi peningkatan kemampuan siswa dalam menyelesaikan soal struktur atom dan sistem periodik, terbukti siswa yang tidak tuntas belajar tinggal 4 orang (13\%), hal ini sulit dihilangkan sebab faktor internal anak itu sendiri. Namun peneliti tetap berusaha untuk memberi bimbingan khusus kepada siswa tersebut di luar jam pelajaran. Sedangkan siswa yang tuntas belajar memperoleh nilai $\geq 66$ ada 26 siswa (87\%) dengan nilai rata-rata kelas pada siklus kedua adalah 79,4 dengan daya serap terhadap pelajaran $80 \%$. berarti ada peningkatan hasil belajar siswa dalam menyelesaikan soal struktur atom dan sistem periodik. Sedangkan pengamatan kegiatan belajar mengajar oleh guru lain, kegiatan guru sudah ada peningkatan dibandingkan siklus pertama 
yaitu perhatian guru sudah menyeluruh dan siswa yang pasif diberi pertanyaan sehingga siswa menjadi aktif.

Memperhatikan hasil penelitian tersebut di atas, dapat dijelaskan bahwa faktor-faktor yang paling banyak menyebabkan siswa mengalami kesulitan dalam menyelesaikan materi yang ada pada pokok bahasan ini adalah siswa tidak terampil dalam menuliskan konfigurasi elektron secara kulit dan sub kulit serta hubungannya dengan bilangan kuantum sehingga jika salah dalam menentukan, siswa akan mengalami kesulitan pada tahap selanjutnya dan menarik kesimpulan.

Tindakan yang harus dilakukan pada siswa yang mengalami kesulitan adalah:

a. Siswa yang tidak memahami soal diberikan soal-soal yang terstruktur dan lebih mudah.

b. Siswa tidak terampil dalam menuliskan konfigurasi elektron secara kulit dan sub kulit serta hubungannya dengan bilangan kuantum dibimbing dan dibantu dengan diberi rambu-rambu dalam menjawab dan alur penyelesaiannya, sehingga siswa lebih mudah menjawabnya.

Kriteria keberhasilan siswa dalam mempelajari materi struktur atom dan sistem periodik adalah :

a. Secara individu bila mereka sudah dapat mencapai 66 atau lebih berarti sudah menyerap materi yang telah diajarkan sebesar $70 \%$ atau lebih dikatakan tuntas belajar.

b. Jumlah siswa dalam kelas dapat menyerap materi $70 \%$ dari jumlah siswa keseluruhan dengan nilai rata-rata kelas mencapai $\geq 70$.

c. Dengan melihat tabel pengamatan oleh guru lain dalam kegiatan belajar mengajar dapat dijelaskan bahwa dalam siklus pertama penguasaan guru terhadap materi pelajaran sudah baik, tetapi perhatian guru kurang merata di seluruh kelas sehingga ada beberapa siswa yang pasif dan sibuk bermain sendiri. Pada siklus kedua kegiatan guru dalam kegiatan belajar mengajar sudah mendekati sempurna, perhatiannya sudah merata seluruh kelas dan siswa kelihatan aktif semua. 


\section{Kesimpulan}

Berdasarkan hasil penelitian dan pembahasan yang telah diuraikan pada bab IV dapat ditarik simpulan sebagai berikut.

Melalui implementasi model pembelajaran kooperatif tife $N H T$ dengan menggunakan periodic table explorer (PT-e) pada materi struktur atom dan sistem periodik, hasil belajar siswa kelas XI IPA 1 tahun 2012 / 2013 SMA Negeri 4 Palopo dapat ditingkatkan

\section{Daftar Pustaka}

Anita Lie. (2002). Cooperative Learning (Mempraktikan Cooperative learning diruang-ruang kelas). Jakarta : Gramedia Widiasarana.

Ani,Tri C. 2004. Psikologi Belajar. Semarang: UPT UNNES Press. Arikunto, Suharsimi, Suhardjono, dan Supardi, 2006, Penelitian Tindakan Kelas, Jakarta, Bina Aksara

Bobbi DePorter, Mark Raerdon, Sarah S. Nourie. (2001). Quantum Teaching. Bandung: Kaifa.

Departemen Pendidikan Nasional. 2006. Model-model pembelajaran efektif

Hamalik, O. 1983. Proses Belajar Mengajar. Jakarta: Bumi Aksara. http://syifadelimapranisasyifadelima.blogspot.com/2011/12/hyperchem.html

Ibrahim, M, dkk. 2000. Pembelajaran Kooperatif. Surabaya: University Press.

Indrawati. 2007. Pembelajaran Kooperatif. Bandung PPPPTK IPA. Lestari Puji H, 2012. Pemanfaatan Media Pembelajaran Berbasis ICT Dalam Pembelajaran Geometri, Jurusan Pendidikan Matematika, Universitas Negeri Yogyakarta

Maftuchah Noor laela, 2011. Pengaruh Pengetahuan, Kegunaan dan Penggunaan Media Berbasis ICT Terhadap Efektivitas Pembelajaran Guru Ekonomi-Akuntansi di SMA SeKabupaten Kudus Tahun Ajaran 2009/2010. Under graduates thesis, Universitas Negeri Semarang.

Nova Dela, 2011. Pemanfaatan Media Pembelajaran Pendidikan Kewarganegaraan Berbasis Teknologi Informasi dan Komunikasi, Under Graduates thesis, Universitas Negeri Semarang. 
Implementasi Model Pembelajaran Kooperatif Tipe NHT dengan

Menggunakan Periodic Table Explorer (PT-e) untuk Meningkatkan Hasil

Belajar pada Siswa Kelas XI IPA 1 SMA Negeri 4 Palopo

Paulina Panen. 2004. Belajar dan Pembelajaran I. Jakarta: Universitas Terbuka.

Purnomo Wahyu,2008. Workshop Pembelajaran Berbasis ICT, Dinas Pendidikan Propinsi Sulawesi Selatan

Popy K, Devi, (2007). Model Pembelajaran Kooperatif. Bandung : PPPPTK IPA.

Tahir, Iqmal, 2003 , Austrian-Indonesian Centre for Comptutational Chemistry Jurusan Kimia, Fakultas MIPA, Universitas Gadjah Mada Yogyakarta

Sahabuddin. 1998. Mengajar dan Belajar. Jakarta: PT Gramedia.

Sudjana, 2000. Model-Model Mengajar CBSA,Bandung: Sinar Baru.

Upu,H. 2003. Problem posing dan problem solving dalam pembelajaran matematika, Pustaka Ramadhan. 